\title{
INVESTIGATING THE MODELLING OF PSYCHOLOGICAL WELL- BEING ACCORDING TO SELF-EXPRESSION AND SELF- EFFICIENCY IN HIGH SCHOOL STUDENTS OF IMAM KHOMEINI RELIEF COMMITTEE
}

\author{
Mansoureh Maleki \\ Islamic Azad University of Central Tehran, \\ malekimansoreh@gmail.com \\ Fatemeh Maleki \\ MSc of women studies, Islamic Azad University of East Tehran \\ Somayyeh Mirzayi \\ MS student of Demography, Islamic Azad University of Roughen \\ Roshanak Farasati \\ Islamic Azad University of Central Tehran
}

\begin{abstract}
Present research has investigated the psychological well-being modelling based on the self-expression and self-efficiency in the high school students of the Imam Khomeini Relief Committee (RA). The aim of this research is to provide a model with a proper fitness. The research method is correlationaldescriptive. The statistical population of this research consists of high school students of Relief Committee studying in the academic year 93-94. A sample of 300 individuals was selected from the statistical population of 1,200 individuals. For collecting data, were used three questionnaires of Reef's psychological well-being, Scherrer's self-efficiency and Gambrill and Ritchie's selfexpression. The reliability and validity of questionnaires have been confirmed by using the Cronbach's alpha. For analyzing data, descriptive tests (variation range, mean and standard deviation) and structural equation model (LISREL) were used. Data analysis shows that the self-expression had a significant and positive effect on self-efficiency and self-efficiency has a significant and positive effect on self-expression. Self-expression has a significant and positive effect on the psychological well-being.
\end{abstract}

Keywords: self-expression, psychological well-being, self-efficiency, Imam Khomeini Relief Committee (RA).

\section{IMAM HUMEYNI YARDIM KOMITESININ LISE ÖĞRENCILERINNDE PSİKOLOJIKK KENDINI İFADE ETME VE KENDİNDEN ETKİNLIĞİNE GÖRE REFAH MODELLEME İNCELEMESI}

ÖZ

Mevcut araştırma İmam Humeyni Yardım Komitesi (RA) lise öğrencilerinde kendini ifade etme ve kendinden verimliliğine dayalı psikolojik iyilik hali modelleme araştırmıştır. Bu araştırmanın amacı uygun bir spor bir model sunmaktır. araştırma yöntemi ilişkisel-açıklayıcı. Bu araştırmanın istatistiksel nüfus öğretim yılı 93-94 okuyan Yardım Komitesi lise öğrencilerinin oluşur. 300 birey bir numunesi 1.200 birey istatistiksel popülasyonundan seçildi. veri toplama, Reef psikolojik esenliği, Scherrer kendini verimliliği ve Gambrill ve Ritchie'nin kendini ifade etme üç anket kullanılmıştır. güvenilirliği ve anketlerin geçerliliği Cronbach alfa ile teyit edilmiştir. veri analizi için, tanımlayıcı testler (değişim aralığı, ortalama ve standart sapma) ve yapısal eşitlik modeli (LISREL) kullanılmıştır. 
Veri analizi kendini ifade kendini verimliliği ve kendini verimliliği üzerinde belirgin pozitif bir etkisi kendini ifade üzerinde önemli bir olumlu etkiye sahip olduğunu göstermektedir. Kendini ifade etme, psikolojik sağlığımız üzerinde önemli ve olumlu bir etkiye sahiptir.

Anahtar Kelimeler: kendini ifade etme, psikolojik iyilik hali, kendine verimlilik, Imam Humeyni Yardım Komitesi (RA).

\section{INTRODUCTION}

Self-expression means the protection of one's own right and belief without breaking others' right and belief (Alberti \& Emmons, 1982). The self-expression is defined also such: a behavior that enables a person to act in his benefit, stands on his two feet without any anxiety, expresses honestly his true feelings and takes his right without disregarding the rights of others. The concept of self-efficiency has been derived from Albert Bandura's theory of the social cognition (1997) that refers to one's beliefs or judgments about his abilities to perform tasks and responsibilities. Thus the human behavior is not only in the control of environment, but also the cognitive processes play an important role in human behavior. Human learning and performance is influenced by cognitive, emotional inclinations, expectations, beliefs and values (Kadivar, 2008). In addition to the above mentioned components which are necessary for psychological well-being and mental health, many human behaviors are motivated and controlled by mechanisms of self-influence. Among the mechanisms of self-influence, person's self-efficiency belief is the most important and comprehensive one (Bandura, 1997). For Bandura the human behavior is not only in environmental control, but also the cognitive processes like self-efficiency have a significant impact on human behavior. Performance and learning of human are influenced by the cognitive inclinations, feelings, expectations, beliefs and values; so the human can influence on his life events and minimize their impact (Schultz, 2005 quoted by Najafi and Fouladchang, 2008).

Researches have shown that self-expression skills and self-efficiency have a relationship with many mental health concepts, because cause to strengthen self-confidence in individuals and encourages their sense of competence and mastery (Mohamadkhani, 2008). Researches show that the well-being of adolescents in the educational environments affects their job future and inclination to continue their education; this effect in turn is transmitted to the economy of society. Therefore, the effects of social environment of schools should be taken seriously, because in addition to the impact on the educational variables such as self-efficiency, they put their psychological basic needs and well-being them under influence (Ryan Vadsy, 2008). The researches conducted in relation to this issue, the findings of Zarean, Asadollahpour and Bakhshipoor (2008), in a research about the relationship between emotional intelligence and mental health show that there is a relationship between emotional intelligence and mental health. In addition to mental health, the emotional intelligence is associated with self-efficiency. In a research entitled as relation mental health and intelligence, Haghshenas, Chamani and Firoozabadi (2007) indicated that the extremely intelligent students have a psychological level better than normal students. In a research entitled the investigation of the beliefs of self-efficiency and mental health, Najafi and Fouladchang (2008) showed that self-efficiency beliefs have a significant relationship with mental health. In a research entitled effectiveness of social skills teaching on self-conception, self-expression and self-efficiency, Jamalzadeh (2000-2001) investigated 17 male adolescent students of Urmia.

According to the research findings we can generally argue that teaching social skills are effective in increasing self-conception and self-expression and self-efficiency, so that teaching social skills can be used to strengthen and improve the above mentioned dependent variables. The findings of Venta et al (2005) show that emotional intelligence is associated positively with the educational achievement and self-efficiency, life satisfaction, mental health or psychological well-being, ways of problem-solving, dealing and behavioral disorders. In their investigation Lyn Y. et al (2004) came to conclusion that self-expression causes to improve compatibility in the social interaction and unsuccessful action of self-expression causes to increase anxiety, depression, disorders in personality and academic achievement and self-efficiency. 


\section{RESEARCH HYPOTHESES}

Hypothesis 1: There is a significant relationship between self-expression and psychological wellbeing.

Hypothesis 2: There is a significant relationship between self-efficiency and psychological wellbeing.

\section{RESEARCH METHOD}

Statistical population of research includes all high school students covered by the Relief Committee in the South East of Tehran. Due to the large volume of statistical population, after obtaining detailed information from Tehran's Relief Committee the sample size was 1,200 individuals for which were estimated 300 individuals. The sample size of this research is at least 225. Finally, for promoting more generalizability and precision of research 300 individuals were considered as the sample size. Data obtained from conducting research by using LISREL and SPSS v22 software and using descriptive statistical methods (mean, standard deviation, percentage) are used for investigating the descriptive characteristics of variables. For analyzing data, the structural equation modeling (maximum likelihood method in LISREL) is used in order to analyze the data based on the framework of the research.

\section{RESEARCH FINDINGS}

\section{FREQUENCY ANALYSIS OF RESPONDENTS IN TERMS OF GENDER}

Frequency analysis of the completed questionnaires shows that $52 \%$ of participants in the research have been male students and the rest female ones. Diagram 1 shows the frequency distribution of participants in research in terms of their gender.

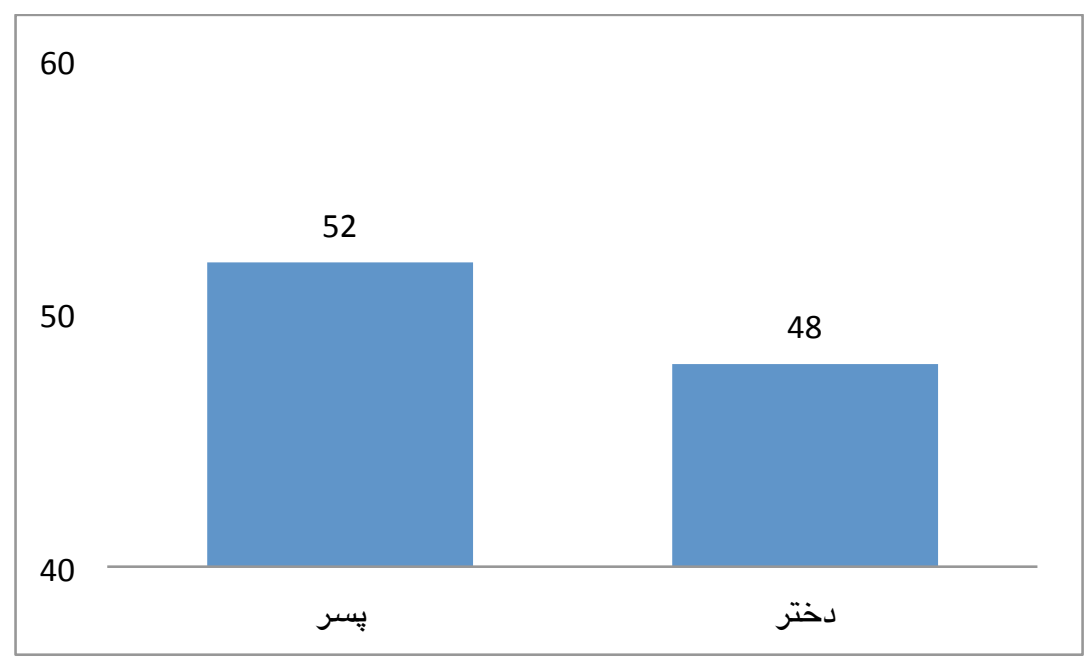

Diagram 1: Percentage of respondents in terms of gender

\section{FREQUENCY ANALYSIS OF RESPONDENTS IN TERMS OF AGE}

Results presented in Diagram 2 show that the 18.3 percent of respondents are of 13 -year old, $24.0 \%$ of 14-year old, 12.3 percent of 15-year old, 14.3 percent of 16-year old, 13 percent of 17 -year old and 18 percent of 18-year old. Thus the highest frequency percentage is related to students of 14-year old and the lowest percentage related to students of 15 -year old. 


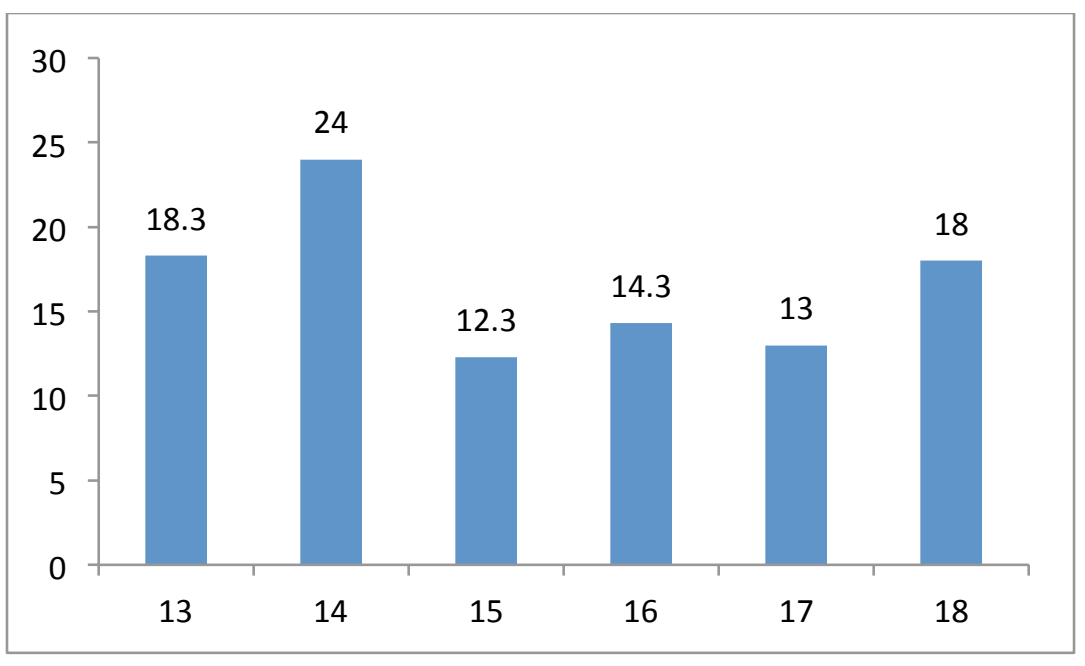

Diagram 2: Percentage of respondents in terms of age

\section{INVESTIGATING THE CONSTITUENT VALIDITY OF THE PSYCHOLOGICAL WELL- BEING CONCEPT}

LISREL software is a powerful tool in evaluating the constituent validity of variables in a form of measurement models. Models that have enough fitness with data and their standardized factor loads are higher than 0.3 and are statistically significant, are known as models that have enough constituent validity. So the first step is to determine the fitness and investigate the indicators of the fitness of models. The concept of psychological well-being has been composed of six subscales; these subscales along with their symbol have been presented in Table 1.

Table 1: Subscales forming the psychological well-being concept

\begin{tabular}{|c|c|c}
\hline Concept & Symbol & Subscale \\
\hline $\begin{array}{c}\text { psychological } \\
\text { well-being }\end{array}$ & Behzis_1 & Self-acceptance \\
\cline { 2 - 3 } & Behzis_2 & $\begin{array}{c}\text { Positive relation } \\
\text { with others }\end{array}$ \\
\cline { 2 - 3 } & Behzis_3 & Autonomy \\
\cline { 2 - 3 } & Behzis_4 & Purposeful life \\
\cline { 2 - 3 } & Behzis_5 & Personal growth \\
\cline { 2 - 3 } & Behzis_6 & $\begin{array}{c}\text { Environment } \\
\text { mastery }\end{array}$ \\
\hline
\end{tabular}

Preliminary results of output of LISREL software showed that the measurement model of the wellbeing concept does not have enough fitness with data. In such circumstances, Schumacher and Lomeks (2006) consider the next step as modifying the model and evaluating the substituted and modified model. In fact the LISREL software has the ability that provides the possibility of modifying the model and its fitness by presenting the suggested routes. Based on the proposals of LISREL software for achieving the goodness of better fitness, in order to solve the problem of lack of fitness we considered the error correlation of a number of variables in the model. The most important indicator of fitness is the ratio of chi-square to degree of freedom. In a model with good fitness, it is expected this indicator is less than 3. As seen in Table 2, value of Chi-square in the fitted model with degree of freedom 5 and the value of 11.41 show that the desired model has enough fitness with data $\left(x^{2} / \mathrm{df}=2.282\right)$. Fitness indicator related to residuals or (RMSEA) decreased also to 0.065 that is 
considered an acceptable amount. GFI coefficient of model has been 0.99 that is higher than 0.9 and indicates the model good fitness with data; also the good fitness coefficient of CFI has been 0.98 , which is also acceptable. (Table 2)

Table 2: indicators of the good fitness of measurement model of psychological well-being

\begin{tabular}{|c|c|c}
\hline Criterion & Obtained value & Acceptable limit \\
\hline $\begin{array}{c}\text { Ratio of Chi- } \\
\text { square to freedom } \\
\text { degree }\end{array}$ & 2.282 & Less than 3 \\
\hline $\begin{array}{c}\text { Good fitness } \\
\text { indicator (GFI) }\end{array}$ & 990. & $\begin{array}{c}\text { Greater than or equal to } \\
0.90\end{array}$ \\
\hline $\begin{array}{c}\text { Comparative } \\
\text { fitness indicator } \\
\text { (CFI) }\end{array}$ & 890.90 \\
\hline $\begin{array}{c}\text { Average root of } \\
\text { approximation } \\
\text { error (RMSEA) }\end{array}$ & 0.065 & $\begin{array}{c}\text { Greater than or equal to } \\
0.90\end{array}$ \\
\hline
\end{tabular}

As previously mentioned, only the coefficients and statistics of the models which have enough and acceptable fitness with data have an interpretability. Figure 1 shows the factor loads of six subscales of psychological well-being based on standard coefficients. As you can see, all factor loads are higher than 0.3 and confirm the constituent validity of the psychological well-being variable. In fact, based on factor loads it can be concluded that the considered dimensions are a proper and valid indicator for measuring the underlying or latent variables (psychological well-being).

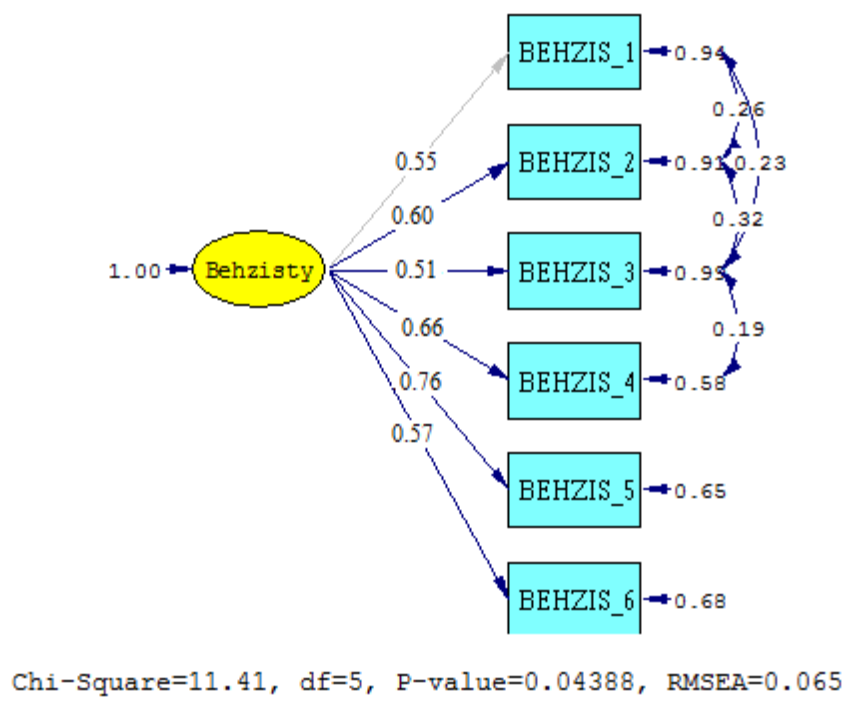

Figure 1: factor loads of subscales of students' psychological well-being (in terms of standard coefficients)

Figure 2 shows also the statistical significance of the produced coefficients in figure 1. Although the produced coefficients in Figure 1 portray the relationships between obvious and hidden variables and have very importance, but they are not by no means sufficient for more accurate understanding of the relationships between variables. In fact, in addition to the standardized coefficients, it is necessary to 
be evaluated also the statistical significance of produced coefficients in Figure 2. In the Figure 2 the coefficients that are greater than 2 , are considered to be statistically significant. As you can see, all factor loads are statistically significant.

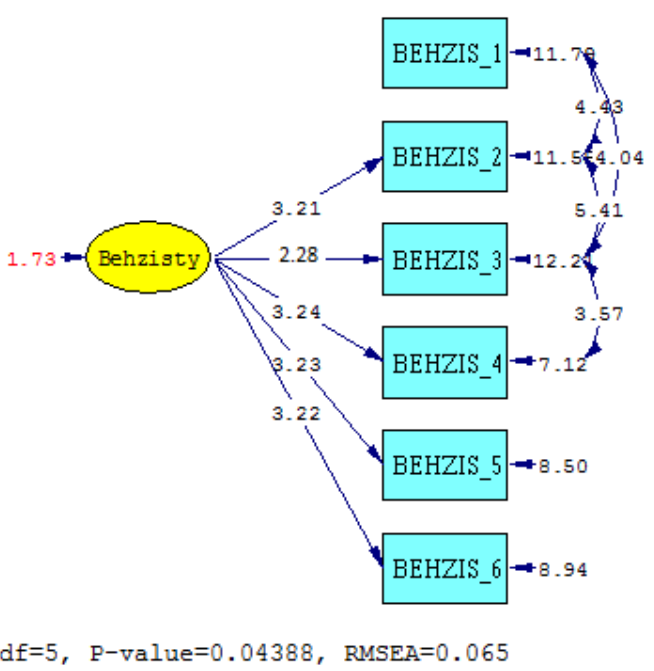

Figure 2: factor loads of subscales of students' psychological well-being (in terms of $t$ coefficients)

Therefore, we can say in total that the psychological well-being variable has the acceptable constituent validity.

\section{INVESTIGATING THE CONSTITUENT VALIDITY OF THE SELF-EXPRESSION CONCEPT}

The second concept of this research is self-expression; in this section like the concept of psychological well-being its constituent validity is estimated. This concept is composed of five subscales: the rejection of request, expressing positive emotions, accepting criticism, accepting difference with others and negative feedback (Table 2).

Table 2: subscales forming the self-expression concept

\begin{tabular}{|c|c|c}
\hline concept & Symbol & subscale \\
\hline $\begin{array}{c}\text { self- } \\
\text { expression }\end{array}$ & Ebraz_1 & Rejecting request \\
\cline { 2 - 3 } & Ebraz_2 & $\begin{array}{c}\text { Expressing positive } \\
\text { feelings }\end{array}$ \\
\cline { 2 - 3 } & Ebraz_3 & Accepting critique \\
\cline { 2 - 3 } & Ebraz_4 & $\begin{array}{c}\text { Accepting difference } \\
\text { with others }\end{array}$ \\
\cline { 2 - 3 } & Ebraz_5 & Negative feedback \\
\hline
\end{tabular}

The results of evaluating the measurement model fitness of self-expression concept show that in the first place this model has good fitness. The results provided in table 3 show that all indicators of model fitness have an acceptable value and so the measurement model of self-expression concept has a appropriate fitness with data.

Table 3: indicators of the good fitness of measurement model of self-expression 
The Turkish Online Journal of Design, Art and Communication - TOJDAC April 2016 Special Edition

\begin{tabular}{|c|c|c}
\hline Criterion & Obtained value & Acceptable limit \\
\hline $\begin{array}{c}\text { Ratio of Chi- } \\
\text { square to freedom } \\
\text { degree }\end{array}$ & 2.282 & Less than 3 \\
\hline $\begin{array}{c}\text { Good fitness } \\
\text { indicator (GFI) }\end{array}$ & 0.96 & $\begin{array}{c}\text { Greater than or equal to } \\
0.90\end{array}$ \\
\hline $\begin{array}{c}\text { Comparative } \\
\text { fitness indicator } \\
\text { (CFI) }\end{array}$ & 0.94 & $\begin{array}{c}\text { Greater than or equal to } \\
0.90\end{array}$ \\
\hline $\begin{array}{c}\text { Average root of } \\
\text { approximation } \\
\text { error (RMSEA) }\end{array}$ & 0.016 & $\begin{array}{c}\text { Less than or equal to } \\
0.07\end{array}$ \\
\hline
\end{tabular}

Figure 3 shows the factor loads of subscales forming self-expression that have been provided in form of standard coefficients. As you can see, all of them are higher than 0.3. So it can be concluded that the factor loads of scales forming self-expression are the valid dimensions in measuring selfexpression.

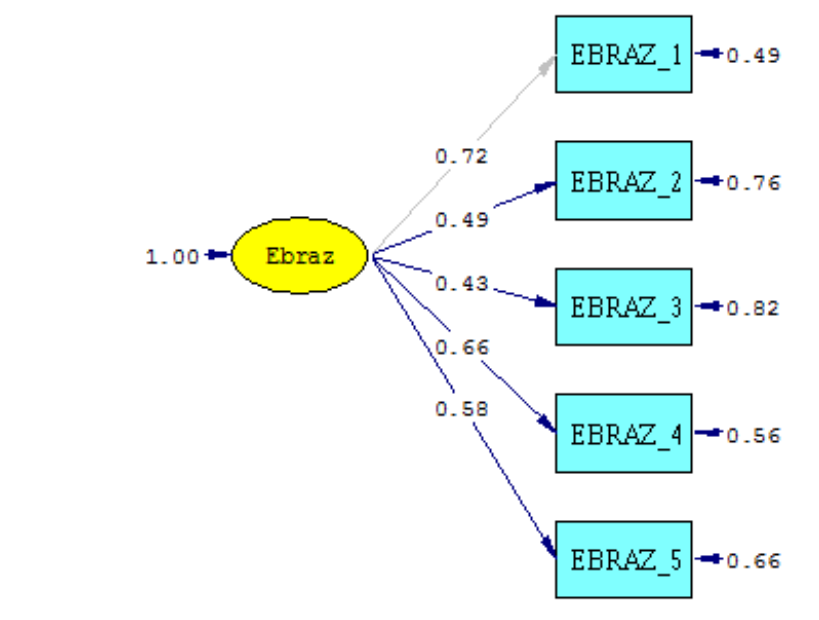

Chi-Square=10.24, df=5, P-value=0.053, RMSEA=0.016

Figure 3: factor loads of subscales of students' self-expression (in terms of standard coefficients)

In addition to values of the factor loads statistical significance of these values should also be investigated and purely this fact that the factor loads are greater than 0.3 , is not sufficient for confirming the constituent validity of variables. Figure 4 shows t coefficients of factor loads of subscales forming self-expression concept. As you can see, all of the coefficients are larger than 2 and therefore are statistically significant. 


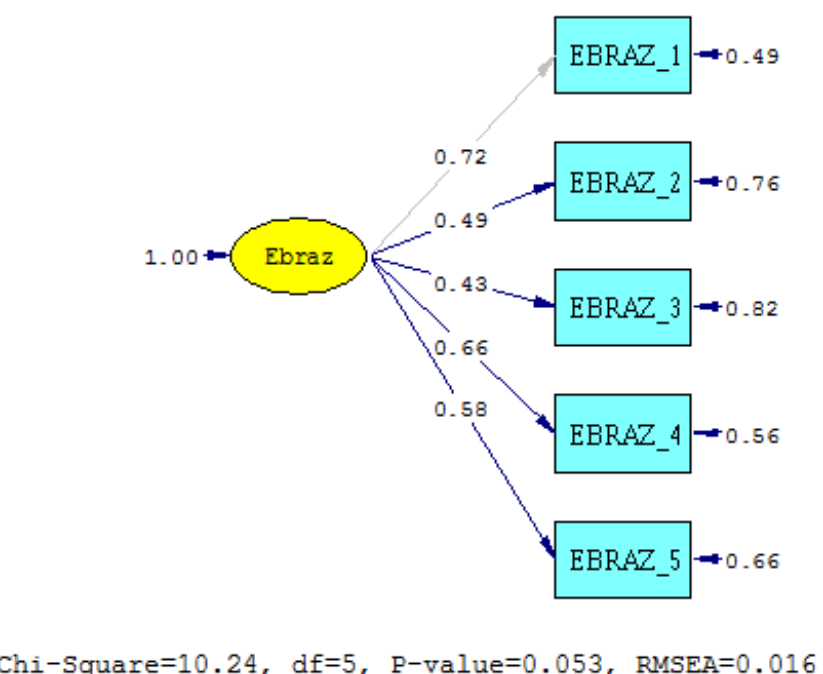

Figure 4: factor loads of subscales of students' self-expression (in terms of t coefficients)

Thus the fitness indicators, the standardized coefficients of factor loads and $t$ coefficients corresponding with them, all of them confirm the constituent validity of self-expression concept and they confirm that the considered subscales are the valid dimensions for measuring self-expression.

\section{INVESTIGATING THE CONSTITUENT VALIDITY OF THE SELF-EFFICIENCY CONCEPT}

The self-efficiency concept has been consisted of three indicators or subscales: tendency to start behavior, tendency to expand endeavor for completing behavior and resistance and confronting with obstacles. Table 4 shows the subscales of self-efficiency concept and the symbols corresponding with these subscales.

Table 4: subscales forming the self-efficiency concept

\begin{tabular}{|c|c|c}
\hline concept & symbol & subscale \\
\hline $\begin{array}{c}\text { self- } \\
\text { efficiency }\end{array}$ & Khodkar_1 & $\begin{array}{c}\text { tendency to start } \\
\text { behavior }\end{array}$ \\
\cline { 2 - 3 } & Khodkar_2 & $\begin{array}{c}\text { tendency to expand } \\
\text { endeavor for } \\
\text { completing behavior }\end{array}$ \\
\cline { 2 - 3 } & Khodkar_3 & $\begin{array}{c}\text { resistance and } \\
\text { confronting with } \\
\text { obstacles }\end{array}$ \\
\hline
\end{tabular}

As proposed previously, the most basic step in the confirmatory factor analysis is to determine the fitness and achievement to a fitted model. Fitness indicators of measuring model of self-efficiency concept have been presented in Table 5. Ratio of Chi-square to degree of freedom has been is 1.91 which is less than 3 and it confirms the model fitness with data. Additionally, the goodness indicators of fitness of GFI CFI have been 0.94 and 0.92 respectively which are larger than 0.9 and it confirms the model fitness with data. RMSEA indicator is also 0.052 and it is another confirmation of the model fitness with data. In summary, all indicators presented in the table below confirm totally adequate fitness of model with data.

Table 5: indicators of the good fitness of measurement model of self-efficiency 


\begin{tabular}{|c|c|c}
\hline Criterion & Obtained value & Acceptable limit \\
\hline $\begin{array}{c}\text { Ratio of Chi- } \\
\text { square to freedom } \\
\text { degree }\end{array}$ & 1.19 & Less than 3 \\
\hline $\begin{array}{c}\text { Good fitness } \\
\text { indicator (GFI) }\end{array}$ & 0.94 & $\begin{array}{c}\text { Greater than or equal to } \\
0.90\end{array}$ \\
\hline $\begin{array}{c}\text { Comparative } \\
\text { fitness indicator } \\
\text { (CFI) }\end{array}$ & 0.92 & $\begin{array}{c}\text { Greater than or equal to } \\
0.90\end{array}$ \\
\hline $\begin{array}{c}\text { Average root of } \\
\text { approximation } \\
\text { error (RMSEA) }\end{array}$ & 0.052 & $\begin{array}{c}\text { Less than or equal to } \\
0.07\end{array}$ \\
\hline
\end{tabular}

In addition to the fitness indicators that have been provided in table 5, the factor loads provided in figure 5 are in total greater than 0.3 and it shows that the considered subscales for self-efficiency are valid indicators in terms of magnitude and size.

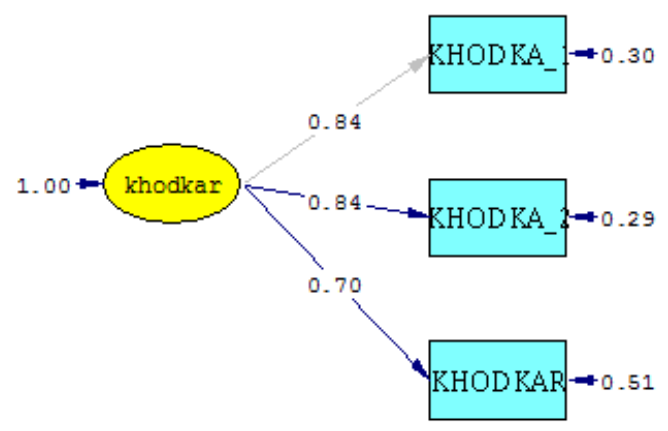

Chi-Square=11.45, df=6, P-value=0.0656, RMSEA=0.052

Figure 5: factor loads of subscales of students' self-efficiency (in terms of standard coefficients)

\section{CONCLUSION}

The above mentioned hypotheses were tested in the form of a conceptual model by using LISREL software. In the conceptual model of this research was assumed that self-expression and selfefficiency have a mutual relation and each of them affect directly the psychological well-being. Proposed indicators confirm totally the adequate fitness of the model with data. The provided factor loads are totally larger than 0.3 and indicate that in terms of size the subscales considered for selfefficiency are valid indicators. The proposed model protects the explanation of the structural relationships among variables (psychological well-being, self-efficiency and self-expression). Test results of this model and rejection or acceptance of the hypotheses of this study have been presented in Table 4. Our results show that each of the hypotheses of research have been confirmed.

Table 4: matrix of hypotheses

\begin{tabular}{|c|c|c|c|c|c}
\hline $\begin{array}{c}\text { Hypothesis } \\
\text { number }\end{array}$ & result & $\begin{array}{c}\mathrm{T} \\
\text { value }\end{array}$ & $\begin{array}{c}\text { Beta } \\
\text { coefficient }\end{array}$ & $\begin{array}{c}\text { Dependent } \\
\text { variable }\end{array}$ & $\begin{array}{c}\text { Independent } \\
\text { variable }\end{array}$ \\
\hline 1 & confirmed & 098. & 0.42 & $\begin{array}{c}\text { Psychological } \\
\text { well-being }\end{array}$ & $\begin{array}{c}\text { Self- } \\
\text { expression }\end{array}$ \\
\hline 2 & confirmed & 4.87 & 0.78 & $\begin{array}{c}\text { Psychological } \\
\text { well-being }\end{array}$ & Self-efficiency \\
\hline
\end{tabular}




\section{RESEARCH SUGGESTIONS}

- Based on the results, the parents whose amount of education and income was lower, have low psychological well-being skills. Therefore, it is appropriate to increase their utility by timely and correct information and teaching the skills.

- Due to the effect of educational environments on children and adolescent's well-being and their effect on protected student's job future and tendency to continue the education and the society's economy, it is recommended that the school's environment is taken in serious (watching over on systematically the schools' environment). Because it affects educational variables such as selfefficiency, as well as their basic psychological needs and well-being. In the field of family education is important for selecting the appropriate school for students.

- Due to the positive effects of the self-esteem and mental health on individuals' destiny and their success, it is recommended that the fields of psychological well-being growth of students' parents are increased by teaching workshops for families in programs of Family Teaching of Committee's cultural section.

- Broadcasting can invite experts and teaching cadres and students for playing role and teach these skills to the public. In this respect, a letter of understanding between the authorities of Committee and education network of Radio and Television can be effective.

\section{REFERENCES}

Bandura, A. (1997). Self-efficacy: The exercise of control. New York: W. H. Freemam.

Haghshenas, H.; A. R. Chamani; A. Firouzabadi (2006), principles of mental health of students of extremely intelligent high schools and normal high schools, Spring and Summer.

Kadivar, P. (1998), psychology of morals, first ed., Tehran, Agah publication.

Lin Y, Shiah S, Chang YC, Lai T, Wang KY, Chou KR. Evaluation of an assertiveness training program on nursing and medical students' assertiveness, selfesteem and interpersonal communication satisfaction. Nursing Education Today 2004; 24(8):656-65.

Mohammadkhani, Sh. (2009), Family risk and protective factors for narcotic drugs use in adolescents Najafi, M.; Foulachang, M. (2009), relationship between self-efficiency and mental health in students, monthly of knowledge and behavior, Shahed University, 2007, No. 23.

Ryan RM, Deci EL (2008). On happiness and human potentials: A review of research on hedonic and eudaimonic wellbeing.

Veneta, A., Bastian, Nicholas R., Burns, Ted Nettelbeck. (2005). Emotional intelligence predicts life kills, but not as well as personality and cognitive،11'pages35

Zarean, M.; A. Asadollahpour; A. Bakhshipour Roudsari (2007), Relation of emotional intelligence and problem-solving styles with general health, psychiatry and clinical psychology journal, thought and behavior, summer of 2007. 